\title{
Inorganic Nitrogen Transformation in Purple Soil as Affected by Major
}

\section{Nitrification Inhibitors in China}

\author{
ZHANG Zhen-zhen ${ }^{1, a}$, SHI Xiao-jun ${ }^{1,2, b}$, LI Hong ${ }^{1, c}$, ZHAO Ya-nan ${ }^{1, d}$, \\ CHEN Xuan-jing ${ }^{1, e}$, LI Dan-ping ${ }^{1, f}$, XIE Jun ${ }^{1, g}$, ZHOU Xin-bin $^{1, h}$, ZHANG \\ Yue-qiang ${ }^{1,2, \text { * }^{*}}$ \\ ${ }^{1}$ College of Resources and Environment, Southwest University, Chongqing 400716, China \\ ${ }^{2}$ National Monitoring Station of Soil Fertility and Fertilizer Efficiency on Purple Soils, Chongqing \\ 400716, China \\ azhen799@email.swu.en, bshixj@swu.edu.cn, cholinlee@163.com, ${ }^{d}$ zhaoyanan86@163.com,

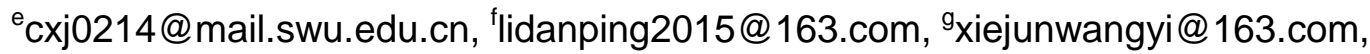 \\ hzxbissas@163.com, levinsky@126.com ("corresponding author)
}

Key words: soils; nitrogen; nitrification inhibitor; nitrogen transformation

Abstract Nitrification inhibitors (NI) are widely used in fertilization to modify nitrogen (N) transformation in soil for matching crop $\mathrm{N}$ requirement and reducing $\mathrm{N}$ loss to environments. However, the effects of major NI products in China on inorganic N transformation in purple soil are poorly quantified. Therefore, incubation experiment was carried out to study the effects of major NI products including Entrench (En), 3,4-dimethylpyrazole phosphate (DMPP) and dicyandiamide (DCD) on inorganic $\mathrm{N}$ transformation in typical purple soil which is the predominant soil in Sichuan Basin, China. With the same incubation condition (soil moisture: 70\% of water hold capacity at $\left.25^{\circ} \mathrm{C}\right)$, the contents of ammonium nitrogen $\left(\mathrm{NH}_{4}{ }^{+}-\mathrm{N}\right)$, nitrite nitrogen $\left(\mathrm{NO}_{3}{ }^{-} \mathrm{N}\right)$, and $\mathrm{pH}$ value were measured, and then the apparent nitrification rate and inhibitory rate of the three nitrification inhibitors were calculated. Results showed that the NI can significantly reduce the acidification rate of the purple soil. And a strong nitrification process was showed in the soil without nitrification inhibitors $(\mathrm{CK})$, with $81.4 \%$ of $\mathrm{NH}_{4}{ }^{+}-\mathrm{N}$ disappearing from the mineral nitrogen pool during the whole incubation period of 100 days. Compared with CK treatment, addition of NI products resulted in a reduced disappearance of $\mathrm{NH}_{4}{ }^{+}-\mathrm{N}$ by $9.8 \%$ for En, $24.6 \%$ for DMPP and $26.1 \%$ for DCD, respectively. The nitrification process of nitrogen in soil was obviously inhibited by NI products, with the inhibition rate of $7.1 \%$ to $95.8 \%$ for DMPP and of $3.8 \%$ to $97.2 \%$ for DCD, respectively. Thus, the nitrification process was delayed by up to 30 days for these two treatments. The inhibition effect of nitrification process by En product was less than that of DMPP and DCD. Under the recommendation rate of NI products, the nitrification inhibition rates were in the order of DCD $(5 \% \mathrm{w} / \mathrm{w})>$ DMPP $(1 \% \mathrm{w} / \mathrm{w})>\operatorname{En}(2.4 \% \mathrm{w} / \mathrm{w})$. We concluded that all the major NI products in China could significantly inhibit the process of nitrification in purple soil. While, DMPP and DCD are superior to En product in maintaining $\mathrm{NH}_{4}{ }^{+}-\mathrm{N}$, inhibiting nitrification process and reducing acidification of the purple soil.

\section{Introduction}

Nitrogen (N) is an essential nutrient for plant growth, $\mathrm{NO}_{3}{ }^{-} \mathrm{N}$ and $\mathrm{NH}_{4}{ }^{+}-\mathrm{N}$ are the main nitrogen 
sources for crop uptake and utilization [1]. Nitrogen is widely used in agricultural production for increasing production efficiency. However, the excessive use of $\mathrm{N}$ fertilizer has resulted in the low rate of $\mathrm{N}$ use efficiency and huge economic waste, both of which may lead to great potential of environmental pollution risk [2-3]. At present, many countries have applied nitrification inhibitors to actual production [4], which makes good effect in reducing $\mathrm{NO}_{3}{ }^{-} \mathrm{N}$ leaching, $\mathrm{N}_{2} \mathrm{O}$ emissions, and increasing $\mathrm{N}$ use efficiency [5]. Therefore, it is of great significance to control the conversion of $\mathrm{N}$ in soil, promote its effective utilization, reduce $\mathrm{N}$ loss and increase the utilization rate of $\mathrm{N}$ fertilizer [6-9]. All are fundamental for $\mathrm{N}$ fertilizer management and environmental protection. Studies on the nitrification inhibitors were mostly adding one kind of nitrification inhibitors in the urea to improve nitrogen use efficiency [6,10]. Except for reducing nitrogen loss, improving the utilization rate of nitrogen fertilizer and increasing crop yield, NI can also reduce the nitrite content in crop species, improve the quality of farm products, and reduce pollution of soil, groundwater and the environment due to the excessive fertilization.

In recent years, both DCD and En (Entrench) have been widely used in agricultural production in foreign countries because they have a strong inhibitory effect on the nitrification process [11]. Studies have shown that using En in agricultural soil can increase corn yield by $7 \%$, reduce the $\mathrm{N}$ leaching loss by $16 \%$ in the mid-western United States [12]. DCD has been widely used in the domestic and foreign agricultural production because of its soluble, not volatile, degradation of safety and high efficiency and other characteristics [13-14]. A large number of field experiments showed that DCD could significantly inhibit the soil nitrification, reduce the leaching of $\mathrm{NO}_{3}-\mathrm{N}$ and $\mathrm{N}_{2} \mathrm{O}$ emissions [15], and the application of DCD in the wheat-rice rotation field could slow down by 11-47\% $\mathrm{N}_{2} \mathrm{O}$ emission [16-20]. DMPP is a new type of nitrification inhibitor in recent years [21-22], although the expensive price, but less dosage, and with less side effect of plant growth and production [23-25]. According to previous studies, DMPP is superior to other similar products in terms of improving the utilization rate of nitrogen fertilizer [26-27]. The inhibition effect of NI was influenced by the factors such as soil, climate, management and crop species.

Although there were many studies about effects of nitrification inhibitors on the conversion of ammonium nitrogen to nitrate nitrogen, the inhibition effect of major nitrification inhibitors on purple soil was not clear in China. By indoor incubation, evaluation of nitrification inhibition effect of different treatments by mixing urea and nitrification inhibitors into purple soil were conducted so as to provide a basis for the efficient utilization of nitrogen fertilizer and environmental protection in Sichuan basin, China.

\section{Materials and Methods}

Soil and Nitrification Inhibitors. The soil used for the incubations was collected from the 0-20cm layer at the National monitoring base for purple soil fertility and fertilizer efficiency (106.26 E, 30.26 N), was located Southwestern University, Beibei District, Chongqing city, China. The initial soil characteristics of the study base are given in Table 1. The soil was air-died, sieved $(<2 \mathrm{~mm})$ and stored at room temperature.

Table 1 Selected initial soil properties at the National monitoring base for purple soil

\begin{tabular}{|c|c|c|c|c|c|}
\hline $\mathrm{pH}$ & $\begin{array}{c}\text { Organic matter } \\
\mathrm{g} \cdot \mathrm{kg}^{-1}\end{array}$ & $\begin{array}{c}\text { Total nitrogen } \\
\mathrm{g} \cdot \mathrm{kg}^{-1}\end{array}$ & $\begin{array}{c}\text { Available nitrogen } \\
\mathrm{mg} \cdot \mathrm{kg}^{-1}\end{array}$ & $\begin{array}{c}\text { Ammonium nitrogen } \\
\mathrm{mg} \cdot \mathrm{kg}^{-1}\end{array}$ & $\begin{array}{c}\text { Nitrate nitrogen } \\
\mathrm{mg} \cdot \mathrm{kg}^{-1}\end{array}$ \\
\hline 7.5 & 9.9 & 0.67 & 69.8 & 3.8 & 17.8 \\
\hline
\end{tabular}


Nitrification inhibitors used in this study included Dicyandiamide (DCD, pure crystalline formulation, 99.5\% ac), 3,4-dimethylpyrazole phosphate (DMPP, pure crystalline formulation, 99.5\% ac ) and 2-chloro-6-(trichloromethyl) pyridine (En, liquid formulation, $22.2 \%$ ac, Dow Agro Sciences).

Incubation Experiments. Incubations were carried out in plastic vials (capacity $500 \mathrm{ml}$ ) using $300 \mathrm{~g}$ soil. The soil was moistened to $70 \% \mathrm{WHC}$ with a solution containing urea $(46.4 \% \mathrm{~N})$ to provide $\mathrm{NH}_{4}{ }^{+} \mathrm{N}$ at $200 \mathrm{mg} \mathrm{kg}^{-1}$ soil. The experiment was performed in a randomized block design with four replicates. And the treatments included: (1) only fertilization (200 mg N per pot) without nitrification inhibitors (control, designated as CK), (2) fertilization (200 mg N per pot) with En $(2.4 \%$ to $\mathrm{N})$, (3) fertilization (200 mg N per pot) with DCD $(5 \% \mathrm{~N})$, and (4) fertilization (200 mg $\mathrm{N}$ per pot) with DMPP $(1 \% \mathrm{~N})$. The loss of moisture content was replenished every week in the course of the incubation. Soil samples were also collected at 2, 4, 9, 18, 35, 50, 50, 65, 80, and 100 days after incubation for determining the content of ammonium, nitrate, nitrite and $\mathrm{pH}$ in soil.

Using the solution of $2 \mathrm{~mol} \cdot \mathrm{L}^{-1} \mathrm{KCl}$ to extract soil $(m(\mathrm{KCl}): m($ Soil $)=5: 1$, shaked 30 minutes $)$, and determined the concentration of ammonium nitrogen, nitrite nitrogen and nitrate nitrogen in soil by Discrete Auto Analyzer (Cleverchem380, DeChem-Tech, Gemany). Other soil physical and chemical properties with reference to the conventional analysis method [28].

Apparent nitrification rate of soil (ANR) and nitrification inhibition rate (NIR) by the test compound were calculated using the following formula:

ANR $(\%)=\left[\mathrm{NO}_{3}{ }^{-}-\mathrm{N} /\left(\mathrm{NH}_{4}{ }^{+}-\mathrm{N}+\mathrm{NO}_{2}{ }^{-}-\mathrm{N}+\mathrm{NO}_{3}{ }^{-}-\mathrm{N}\right)\right] \times 100$

$\mathrm{NIR}(\%)=(\mathrm{A}-\mathrm{B}) / \mathrm{A} \times 100$

Where $\mathrm{A}$ is the amount of $\left(\mathrm{NO}_{3}{ }^{-}+\mathrm{NO}_{2}{ }^{-}\right)-\mathrm{N}$ produced in the soil sample treated with the test compound and $\mathrm{B}$ is the amount of $\left(\mathrm{NO}_{3}{ }^{-}+\mathrm{NO}_{2}{ }^{-}\right)-\mathrm{N}$ produced by the control sample (no test compound added).

\section{Result}

Effects of Different Types of Nitrification Inhibitors on pH value in Purple Soil. Fig. 1 showed that the soil $\mathrm{pH}$ of all treatments was increased firstly and then reduced with the growth of the incubation time in the whole process. This will inevitably lead to the increase of soil $\mathrm{pH}$, because soil maintain a higher $\mathrm{NH}_{4}{ }^{+}-\mathrm{N}$ content and lower $\mathrm{NO}_{3}{ }^{-}-\mathrm{N}$ content for a long time with the application of nitrification inhibitors. The soil $\mathrm{pH}$ of each treatment reached to the highest on the second day, which were 8.0 (CK), 8.2 (En), 8.3 (DMPP) and 8.3 (DCD), respectively. And then the $\mathrm{pH}$ values began to decline at different range. The soil $\mathrm{pH}$ of $\mathrm{CK}$ treatment was decreased sharply, $\mathrm{pH}$ has fallen from 7.5 at the beginning to 6.3 on the eighteenth day, a decline of 1.2 units, and then decreased slowly from 19 to 100 days, the soil $\mathrm{pH}$ values dropped down to 6.1 at the end of the incubation. The soil $\mathrm{pH}$ decreased significantly slower of the treatments adding nitrification inhibitors, compared with the initial incubation. On the thirty-fifth day, the decline of soil $\mathrm{pH}$ of En, DMPP and DCD were 0.9, 0.3, 0.1 units, respectively, a decline of treatments were significantly lower than that of CK $(\mathrm{p}<0.01)$. The soil $\mathrm{pH}$ of En, DMPP and DCD treatments were significantly higher than CK treatment $(\mathrm{p}<0.01)$ from the second day of incubation, but there was no significant difference between En and DMPP. It can be seen that adding nitrification inhibitor to the soil can significantly slow down the rate of soil acidification. 


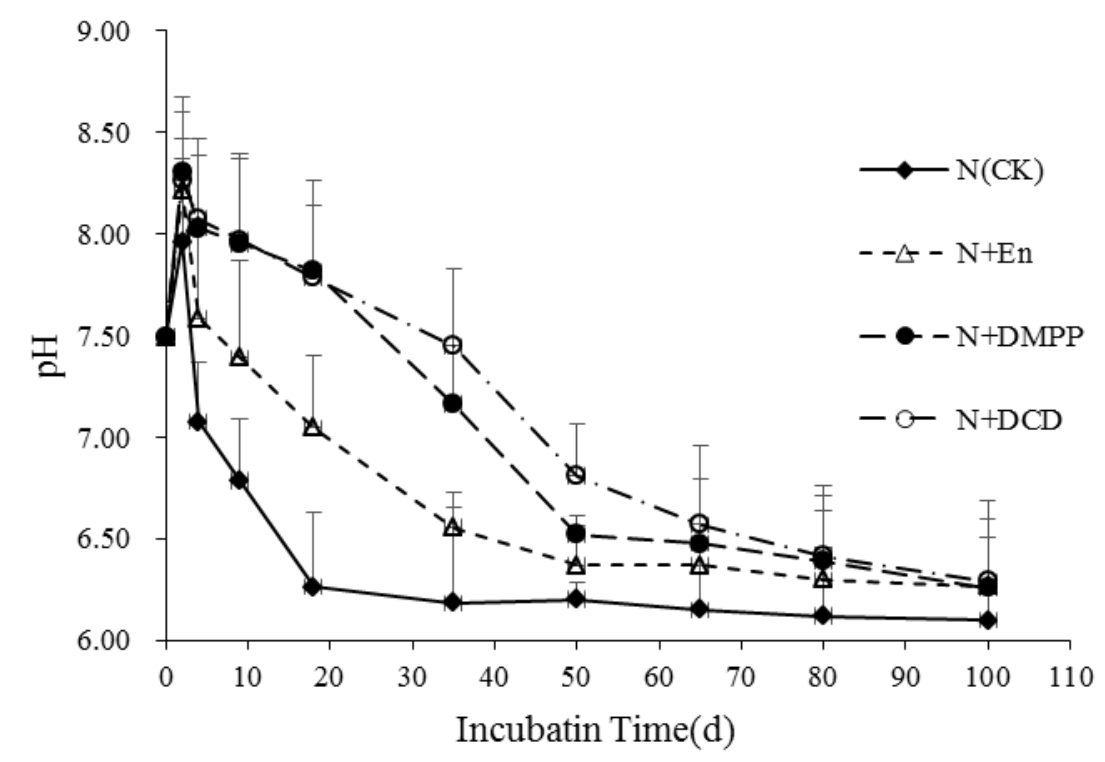

Fig. 1 Soil $\mathrm{pH}$ in purple soil with different nitrification inhibitors

\section{Effects of Different Types of Nitrification Inhibitors on Nitrogen Forms in the Process of Urea Conversion}

Effects of Different Types of Nitrification Inhibitors on $\mathrm{NH}_{4}{ }^{+}-\mathrm{N}$ Content in Purple Soil. In the culture process, the transformation of urea was inhibited by the addition of nitrification inhibitors, which first showed the increase of the content of $\mathrm{NH}_{4}{ }^{+}-\mathrm{N}$ in soil or the decrease of $\mathrm{NO}_{3}{ }^{-} \mathrm{N}$ content. As can be seen from Fig. 2, all of the added nitrification inhibitor treatment of soil $\mathrm{NH}_{4}{ }^{+}-\mathrm{N}$ content was higher than the $\mathrm{CK}$ treatment, in the whole process of culture. The content of $\mathrm{NH}_{4}{ }^{+}-\mathrm{N}$ in each treatment soil showed the trend was increased in the beginning and then decreased with the increase of culture time, which was similar to the change trend of $\mathrm{pH}$ in Fig. 1. The $\mathrm{NH}_{4}{ }^{+}-\mathrm{N}$ content of all treatments reached a peak at the second day of culture, and then began to decrease. The $\mathrm{NH}_{4}{ }^{+}-\mathrm{N}$ content of CK treatment decreased fastest, from $118.72 \mathrm{mg} / \mathrm{kg}$ on the second day down to $5.89 \mathrm{mg} / \mathrm{kg}$ on the thirty-fifth day, a decline of $95 \%$, then began to slow down; the En treatment of $\mathrm{NH}_{4}{ }^{+}-\mathrm{N}$ content in the thirty-fifth day decreased by $80.74 \%$, DMPP and DCD were decreased by $62.3 \%$ and $54.5 \%$, respectively, the decline of nitrification inhibitors treatments were significantly lower than that of $\mathrm{CK}(\mathrm{p}<0.01)$. The changes about $\mathrm{NH}_{4}{ }^{+}-\mathrm{N}$ content of DCD and DMPP treatments were consistent in the culture period, and DCD treatment was slightly higher than that of DMPP treatment; while the $\mathrm{NH}_{4}{ }^{+}-\mathrm{N}$ content of En treatment decreased relatively quickly. The inhibitory effect of DCD and DMPP was better than that of En during the incubation. 


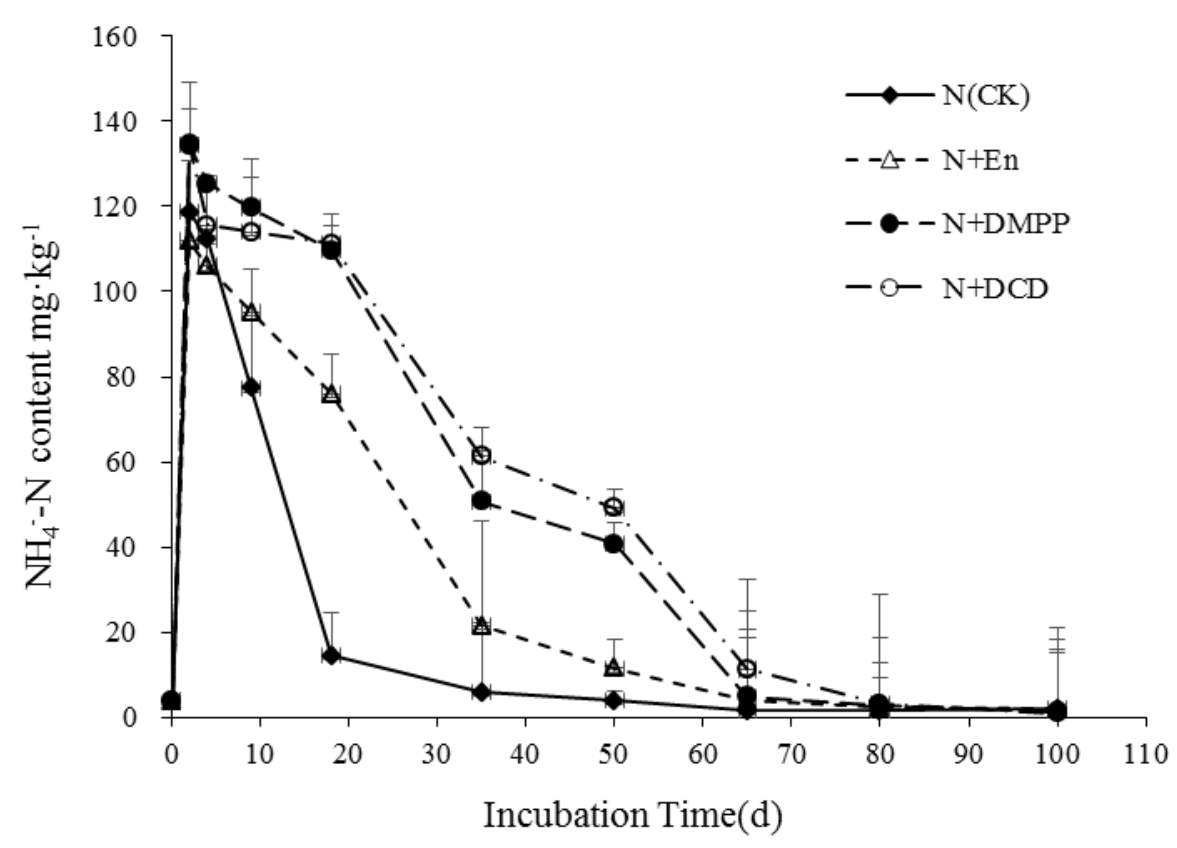

Fig. 2 Concentration of $\mathrm{NH}_{4}{ }^{+}-\mathrm{N}$ in purple soil with different nitrification inhibitors

Effects of different types of nitrification inhibitors on $\mathrm{NO}_{3}^{-}-\mathrm{N}$ content in purple soil. In contrast to the $\mathrm{NH}_{4}{ }^{+}-\mathrm{N}$ content, the content of $\mathrm{NO}_{3}{ }^{-} \mathrm{N}$ in soil was increased gradually with the increase of incubation time, and the change trend was similar with treatments. From the beginning, the application of nitrification inhibitor treatment, showed the inhibition effect on ammoxidation, $\mathrm{NO}_{3}{ }^{-}-\mathrm{N}$ content in the soil were lower than $\mathrm{CK}$ treatment, and continued until the end of the experiment. The $\mathrm{NO}_{3}{ }^{-} \mathrm{N}$ content of $\mathrm{CK}$ treatment increased rapidly at the beginning, reached $165.2 \mathrm{mg} / \mathrm{kg}$ on 18 days' incubation, then $\mathrm{NO}_{3}{ }^{-} \mathrm{N}$ content increased slowly; $\mathrm{NO}_{3}{ }^{-} \mathrm{N}$ content of En, DMPP and DCD treatments were $116.5,44.5$ and $63.5 \mathrm{mg} / \mathrm{kg}$, respectively, at the 18 days of incubation, all of which were significantly lower than that of CK $(\mathrm{p}<0.01)$. After 25 days of incubation, $\mathrm{NO}_{3}{ }^{-} \mathrm{-N}$ content of En, DMPP and DCD treatments were $165.6,123.5$ and $90.8 \mathrm{mg} / \mathrm{kg}$, respectively. And DMPP and DCD treatments were significantly lower than that of CK $(\mathrm{p}<0.01)$, but there was no significant difference between En and CK treatments. However, the $\mathrm{NO}_{3}{ }^{-} \mathrm{N}$ content of each nitrification inhibitor treatment was significantly different $(\mathrm{p}<0.01)$. During the whole incubation period, the $\mathrm{NO}_{3}{ }^{-} \mathrm{N}$ content of DCD treatment was basically at the lowest level, the inhibition effect was better than that of DMPP and En treatment, and the followed is DMPP treatment. 


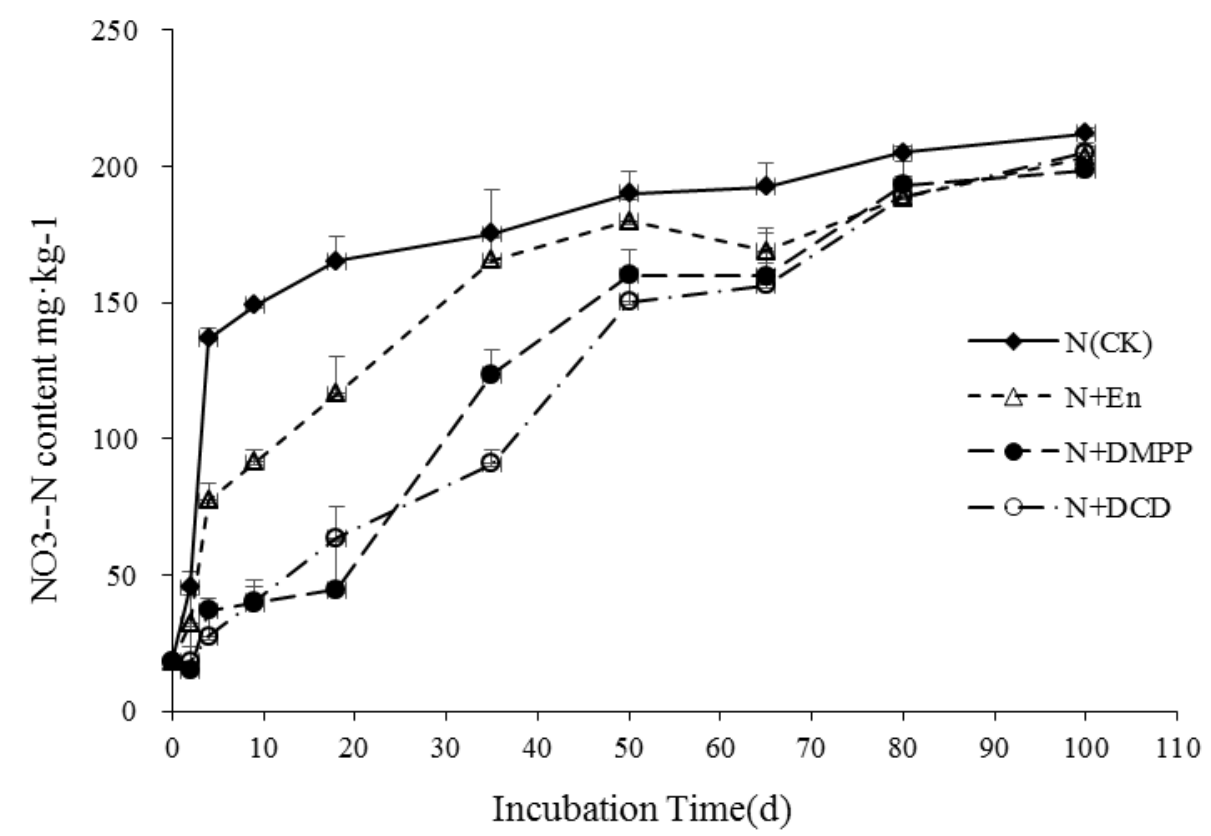

Fig. 3 Concentration of $\mathrm{NO}_{3}{ }^{-} \mathrm{N}$ in purple soil with different nitrification inhibitors

\section{Effects of Different Types of Nitrification Inhibitors on the Apparent Nitrification Rate and Nitrification Inhibition Rate of Soil}

Apparent Nitrification Rate of Soil. The percentage of $\mathrm{NO}_{3}{ }^{-} \mathrm{N}$ content accounted for mineral nitrogen in soil is called soil apparent nitrification rate, the lower the value, the weaker the nitrification inhibitory, the higher the value, the higher the nitrification intensity. Overall, the apparent nitrification rate of different treatments in purple soil showed a gradual increasing trend with the extension of incubation time (Table 1). In the first 9 days of culture, the apparent nitrification rate of CK was between $27.3 \% \sim 65.5 \%$, and then increased rapidly to $91.8 \%$, reaching $99.1 \%$ at the end (Table 1). Adding nitrification inhibitors had a significant inhibitory effect on nitrification of soil nitrogen, which En, DMPP and DCD were lower than the CK in the first 80 days of incubation, then began to achieve that of CK level gradually. The apparent nitrification rate of DMPP and DCD treatments were in a low level in the first 50 days of culture, which were respectively between $9.8 \% \sim 79.7 \%$ and $11.7 \% \sim 75.3 \%$, significantly lower than En treatment.

Table 1 Apparent nitrification rate of different treatments in purple soil

\begin{tabular}{llrrrrrrrr}
\hline \multirow{2}{*}{ Treatment } & \multicolumn{10}{c}{ Incubation $(\mathrm{d})$} \\
\cline { 2 - 10 } & 2 & 4 & 9 & 20 & 35 & 50 & 65 & 80 & 100 \\
\hline $\mathrm{N}(\mathrm{CK})$ & $27.3 \mathrm{a}$ & $54.6 \mathrm{a}$ & $65.5 \mathrm{a}$ & $91.8 \mathrm{a}$ & $96.6 \mathrm{a}$ & $97.9 \mathrm{a}$ & $99.2 \mathrm{a}$ & $99.2 \mathrm{a}$ & $99.1 \mathrm{a}$ \\
$\mathrm{N}+$ En & $21.9 \mathrm{a}$ & $41.8 \mathrm{~b}$ & $41.8 \mathrm{~b}$ & $60.5 \mathrm{~b}$ & $88.4 \mathrm{~b}$ & $93.9 \mathrm{a}$ & $97.7 \mathrm{a}$ & $98.8 \mathrm{a}$ & $99.1 \mathrm{a}$ \\
$\mathrm{N}+$ DMPP & $9.8 \mathrm{~b}$ & $22.5 \mathrm{c}$ & $24.8 \mathrm{c}$ & $28.8 \mathrm{c}$ & $70.8 \mathrm{c}$ & $79.7 \mathrm{~b}$ & $96.9 \mathrm{a}$ & $98.5 \mathrm{a}$ & $99.3 \mathrm{a}$ \\
$\mathrm{N}+$ DCD & $11.7 \mathrm{~b}$ & $18.9 \mathrm{c}$ & $26.1 \mathrm{c}$ & $36.3 \mathrm{~d}$ & $59.7 \mathrm{~d}$ & $73.5 \mathrm{~b}$ & $93.2 \mathrm{~b}$ & $98.4 \mathrm{a}$ & $99.5 \mathrm{a}$ \\
\hline
\end{tabular}

Nitrification Inhibition Rate. Nitrification inhibition rate of En treatment is between $33.1 \%$ $48.5 \%$ in the first 20 days of incubation (Table 2), and then reduced the inhibition rate to $6.0 \%$ after 15 days of incubation, and it was $4.4 \%$ at the end of incubation. The inhibition rate of DCD and DMPP treatments were between $81.9 \% \sim 95.8 \%$ and $69.0 \%$ $97.2 \%$ in the first 20 days, then DCD treatment was decreased rapidly, DMPP treatment was slow down. In the first 70 days of 
culture, the nitrification inhibition rate of DCD and DMPP treatments were higher than that of En treatment. After that, the difference of the inhibition rate of each treatment became smaller.

Table 2 Nitrification inhibition rate of DMPP, DCD, and En in purple soil

\begin{tabular}{cccccccccc}
\hline & \multicolumn{7}{c}{ Incubation (d) } \\
\cline { 2 - 10 } Treatment & 2 & 4 & 9 & 20 & 35 & 50 & 65 & 80 & 100 \\
\hline N+En & $48.5 \mathrm{a}$ & $50.1 \mathrm{a}$ & $43.1 \mathrm{a}$ & $33.1 \mathrm{a}$ & $6.2 \mathrm{a}$ & $6.0 \mathrm{a}$ & $13.5 \mathrm{a}$ & $8.8 \mathrm{a}$ & $4.4 \mathrm{a}$ \\
N+DMPP & $95.8 \mathrm{~b}$ & $84.0 \mathrm{~b}$ & $83.1 \mathrm{~b}$ & $81.9 \mathrm{~b}$ & $32.9 \mathrm{~b}$ & $17.5 \mathrm{~b}$ & $18.7 \mathrm{a}$ & $6.4 \mathrm{a}$ & $6.7 \mathrm{ab}$ \\
N+DCD & $97.2 \mathrm{~b}$ & $92.0 \mathrm{~b}$ & $82.6 \mathrm{~b}$ & $69.0 \mathrm{c}$ & $53.7 \mathrm{c}$ & $23.1 \mathrm{c}$ & $20.7 \mathrm{a}$ & $8.6 \mathrm{a}$ & $5.1 \mathrm{ab}$ \\
\hline
\end{tabular}

\section{Discussion}

The change of $\mathrm{pH}$ was the same with ammonium nitrogen in each treatment during the incubation period, which was mainly related to the transformation of nitrogen in soil. The soil $\mathrm{pH}$ reached the highest value on the second day of incubation, because it will hydrolyzed into ammonium nitrogen quickly under suitable conditions by fertilizing urea in soil, soil ammonium nitrogen accumulation in a short period of time, and then caused the rise of soil pH inevitably [31]. The following nitrification, oxidized ammonium nitrogen into nitrate nitrogen, the release of $\mathrm{H}^{+}$in this process decreased soil $\mathrm{pH}$ [32]. But the decline of CK treatment was the largest and had been at the lowest level because of rapid nitrification. The soil $\mathrm{pH}$ of En, DMPP and DCD treatments increased $0.79,1.52$ and 1.56 units, respectively, compared with $\mathrm{CK}$ treatment on the twentieth day of incubation. This result is similar to that reported in other literatures [5,31,33]. Soil $\mathrm{pH}$ was an important factor to affect nitrification, nitrification rate was significantly positively correlated with soil $\mathrm{pH}$ [34-35]. That is the nitrification rate of soil increased with the increase of $\mathrm{pH}$ within $\mathrm{pH}$ from 5.6 to 8, it is relevant to the autotrophic nitrifying bacteria grow better in $\mathrm{pH}$ was 6.6 8.0 or higher range [36].

In this experiment, all these three nitrification inhibitors can significantly slow down the conversion of ammonium nitrogen to nitrate nitrogen in the early stage of incubation. On the one hand, it can promote the absorption of ammonium nitrogen by crops to maintain high level of ammonium nitrogen in soil for a longer time. On the other hand, soil colloids can also fix ammonium nitrogen partly, to reduce nitrate leaching, it was the same with the results of previous studies [5,37-38]. In this study, the ammonium nitrogen content of CK treatment reached the highest peak in the incubation of the first 2-4 days, then the ammonium nitrogen was converted to nitrate nitrogen, ammonium nitrogen content decreased rapidly (Fig. 2). In contrast, En, DMPP and DCD treatments maintained a higher level of ammonium nitrogen content in the early stage of culture, and the lower decline (Fig. 2). The nitrification inhibition of NI treatments gradually weakened in the late stage as the longer time, e.g., after 60 days, the treatments of soil ammonium nitrogen content tends to balance and there is no significant difference.

On the temporal effect of nitrification inhibition, apparent soil nitrification rate (Table 1) and nitrification inhibition rate (Table 2) showed that En, DMPP and DCD treatments can delay soil nitrification, comparing with CK treatment. And the inhibitory effect of DMPP and DCD is stronger than that of En. The period to keep the nitrification inhibitor in soil is one of the key factors which decide the nitrification inhibition effect [39]. But the inhibition effects of different nitrification inhibitors are affected by soil physical and chemical factors including soil moisture, organic matter, soil $\mathrm{pH}$, soil type, soil pore water filling rate, soil microorganism, and different doses of nitrification inhibitors and so on [40-42]. All these factors could affect the adsorption in 
the soil and inhibitory effect. DCD has lower price, less volatile, but easy to occur leaching loss because of the higher water solubility [38], and the misuse is easy to lead to harm to the plant [43-44]. En is generally in the form of emulsion and water emulsion, difficult to dissolve in water, but has some inconvenience in use and storage because of the volatile and photolysis; and En is one kind of organic chloride, it will has a negative impact on the environment and crop with a large dosage [15]. DMPP has the higher the price, but it has the lower dosage, slower degradation rate and better plant compatibility etc., and the inhibitory effect is much higher than DCD [44-45]. Comprehensive consideration, DMPP is therefore an ideal nitrification inhibitor for regions with purple soils.

\section{Conclusion}

Nitrification inhibitors of DCD, DMPP and En can reduce the conversion rate of soil ammonium nitrogen at different degrees, and slow down the nitrification process of transforming ammonium nitrogen to nitrate nitrogen. The inhibition effect of DCD and DMPP on soil nitrification was very close, which the nitrification of the soil was delayed by at least 30 days. The En inhibition was relatively weak, and the nitrification of the soil could be delayed by about 20 days. Compared with the control treatment, it can decrease the decline rate of soil $\mathrm{pH}$ significantly by adding nitrification inhibitor, which showed that adding nitrification inhibitor could slow down the rate of soil acidification significantly, and promote plant growth. The order of inhibition ability of nitrification inhibitor is DCD $(5 \% \mathrm{~N})>\mathrm{DMPP}(1 \%)>\mathrm{En}(2.4 \%)$ under the laboratory conditions and the recommended concentration of market conditions. The $\mathrm{N}$ inhibiting effect of DCD and DMPP were comparable, but significantly higher than that of En. Considering the price, efficiency and application of NI products, DMPP is an ideal nitrification inhibitor for regions with purple soils.

\section{Acknowledgments}

This study was jointly supported by the National Key Technology Research and Development Program (2015BAD06B04), the National Natural Science Foundation of China (41401320, 31471944, 41371301 and 31372141), Postdoctoral Science Foundation of China (2013M542244), Advanced and Applied Basic Research Program of Chongqing (cstc2014jcyjA50014), Doctor Foundation of Southwest University (20710922), and Fundamental Research Funds for the Central Universities (2362015xk06).

\section{References}

[1] Z. L. Zhu: Acta Pedologica Sinica. Vol. 05(2008), p. 778-783

[2] W. L. Zhang, Z. X. Tian and N. Zhang: Ecosystems and Environment. Vol. 59(1996), p. 223-231

[3] D. L. Liang, K. Q. Wu and S. X. Li: Journal of Northwest A \& F University: Natural Science Edition. Vol. 35(2007), p. 94-98 (in Chinese).

[4] M. Singh, S. Pabbi, A. K. Bhattacharya and A. K. Sing: Agricultural Water Management. Vol. 91(2007), p. 78-85

[5] M. Shi, D. L. Liang and N. Man: Scientia Agricultura Sinica. Vol. 22(2012), p. 4635-4642 
[6] Q. G. Yu, Y X Chen: Journal of Agro-Environment Science. Vol. 07(2011), p. 1357-1363

[7] M. Trenkel: Paris: International Fertilizer industry Association(1997)

[8] L. M. Chuan, T. K. Zhao, Z. Z. An, L. F. Du and S. J. Li: Journal of Agro-Environment Science. Vol. 29(2010), p. 870-874

[9] W. R. Cookson and I. S. Cornforth: Soil Biology and Biochemistry. Vol. 34(2002), p. 1461-1465

[10]K. L. Sahrawat: Plant and Soil. Vol. 147(1980), p. 283-291

[11]N. I. Lopez, A. T. Austin, O. E. Sala and B. S. Méndeza: Soil biology \& biochemisty. Vol. 35(2003), p. 1609-1613

[12]J. D. Wolt: Nutrient Cycling in Agroecosystems. Vol. 69(2004), p. 23-41

[13]C. A. Grant and L. D. Bailey: Can. J. Plant Sci. Vol. 79(1999), p. 491-496

[14]Z. L. Zhu and D. L. Chen: Nutr. Cycl. Agroecosyst. Vol. 63(2002), p. 117-127

[15]M. M. Zhang, J. P. Shen, J. Z. He and L. M. Zhang: Journal of Agro-Environment Science. Vol. 11(2014), p. 2077-2083

[16]P. Boeckx, X. Xu and O. Van Cleemput: Nutr. Cycl. Agroecosyst. Vol. 72(2005), p. 41-49

[17]X. L. Li, G. B. Zhang, H. Xu, Z. C. Cai and Y. kazuyuki: Chemosphere. Vol. 75(2009), p. $1417-1422$

[18]U. Kumar, M. C. Jain, H. Pathak, S. Kumar and D: Biol. Fertil. Soils. Vol. 32(2000), p. 474-478

[19]D. Majumdar, H. Pathak, S. Kumar and M. C. Jain: Agricult. Ecosyst. Environ. Vol. 91(2002), p. $283-293$

[20]G. Malla, A. Bhatia, H. Pathak, S. Prasad, N. Jain and J. Singh: Chemosphere. Vol. 58(2005), p. $141-147$

[21]Q. G. Yu and Y. X. Chen: China Environmental Science. Vol. 30(2010), p. 1274-1280

[22]W. Zerulla, T. Barth, J. Dressel, K. Erhardt, K. Horchler von Locquenghien, G. Pasda, M.

Rädle and A. Wissemeier: Biology and Fertilizer of Soils. Vol.34(2001), p. 79-84

[23]A. Weiske, G. Benckiser, T. Herbert and J. Ottow: Biol Fert Soils. Vol. 34(2001), p. 109-117.

[24]A. H. Wissemeier, W. Linzmeier, R. Gutser, W. Weigelt and U. Schmidhalter. In Plant Nutrition: Food security and sustainability of agroecosystems (Kluwer Academic Publishers, Netherlands, 2001).

[25]X. M. Macadam, A. del Prado, P. Merino, J. M, M. Pinto and C. González-Murua: Plant Physiol. Vol. 160(2003), p. 1517-1523

[26]I. Irigoyen, J. Muro, M. Azpilikueta, P. Aparicio-Tejo and C. Lamsfus: Australian Journal of Soil Research. Vol. 41(2003), p. 1177-1183

[27]M. D. Serna, J. Banuls, A. Quifiones and F. Legaz: Biology and Fertility of Soils. Vol. 31(2000), p. $41-46$ 
[28]S. D. Bao: Analysis of Soil and Agricultural Chemistry ( China Agricultural Press, Beijing 2000)

[29]J. H. Lin, H. X. Li, F. Hu and H. Y. Zhao: Acta Pedologica Sinica. 41(2004), p. 924-930

[30]G. W. Mc Carty and J. M. Bremner: Biology and Fertility of Soils. Vol. 8(1989), p. 204-211

[31]M. T. Zhang: Northwest A \& F University(2010)

[32]M. L. Cabrera, D. E. Kissel and B. R. Bock: Soil Biol Biochem. Vol. 23(1991), p. 1121-1124

[33]W. R. Cookson and I. S. Cornforth: Soil Biology and Biochemistry. Vol. 34(2002), p. 14611465

[34]H. L. Jensen: Archives of Microbiology. Vol. 28(1957), p. 145-152

[35]H. X. Li, F. Hu, M. Q. Liu, G. X. Cai and X. H. Fan: Soils. Vol. 32(2000), p. 194-197 (in Chinese).

[36]L. Yu, M. Gao, E. Ci, Z. F. Wang, C. F. Wei and C: Ecology and Environmental Sciences. 19(2010), p. 733-738

[37]B. Chaves, A. Opoku, S. De Neve, P. Boeckx, O. Van Cleemput and G. Hofman: Boil Fertil Soils. Vol. 43(2006), p. 62-68

[38]A. Week, G. Benckiser, T. Herbert and J. C. G. Ottow: Boil Fertil Soils. Vol. 34(2001), p. 109-117

[39]J. F. Ning, L. H. Cui, S. Y. Ai, R. H. Wang, J. W. Yao, M. J. Li, Z. B. Zeng and S. Y. Wang: Transactions of the Chinese Society of Agricultural Engineering. Vol. 04(2015),p. 144-151

[40]L. Vitale, L. Ottaiano, F. Polimeno, G. Maglione, U. Amato, C. Arena, P. Di Tommasi1, M. Mori and V. Magliulo: Plant Soil and Environment. Vol. 59(2013), p. 517-523

[41]J. Z. Yin, Q. G. Yu, J. R. Fu, J. W. Ma, P. Zhou, X. X. Wang, J. Fei and X. B. Fang: ActaPedologica Sinica. Vol. 50(2013), p. 574-583

[42]G. Barth, S. von Tucher and U. Schmidhalter: Biology and Fertility of Soils. Vol. 34(2001), p. 98-102

[43]Z. M. Sun, Z. J. Wu, L. J. Chen and X. Z. Ma: Chinese Journal of Applied Ecology. Vol. 19(2008), P. 1611-1618

[44]W. Zerulla, T. Barth, J. Dressel, K. Erhardt, K. Horchler von Locquenghien and G. pasda: Biology and Fertility of Soils. Vol. 34(2001), p. 79-84

[45]H. J. Di and K. C. Cameron: Soil Use and Management, 2012, Vol. 28(2012), p. 54-61 